http://dx.doi.org/10.4314/jae.v16i2.11

\title{
Sources of Awareness and Perception of the Effects of Climate Change among Sesame Producers in the Southern Agricultural Zone of Nasarawa State, Nigeria
}

\author{
*Luka, E. G. and Yahaya, H. \\ * Corresponding author E-Mail:lukezy2000@yahoo.com \\ Mobile phone: 08036149840 \\ Department of Agricultural Economics and Extension, Nasarawa State University, \\ Keffi.
}

\begin{abstract}
The study was conducted to determine the sources of awareness of climate change and ascertain the perception of the effects among sesame producers in the Southern Agricultural Zone of Nasarawa State, Nigeria. A multistage random sampling technique was used in selecting 180 sesame farmers that participated in the study. Descriptive statistics were used in analyzing data. Major results show that both males and females mostly (40\%) between the ages of 31-40 years were involved in sesame production. The level of education was low. Increased rains, insect infestation and torrential downpours were perceived as effects of climate change. Sesame farmers' had adapted to such changes through the use of chemicals, insect powders, early planting and early harvesting. Results also show that extension agents, radio and television were the major sources of awareness of the effects of climate change. The study concluded with the recommendation that farmers' awareness of the devastating effects of climate change is very critical for helping them adapt to climate change and need to be urgently strengthened by extension service so as to sustain sesame production even in the event of climate change.
\end{abstract}

Keywords: Sources of Awareness, Perception, Climate Change, Sesame, Nasarawa state

\section{Introduction}

Sesame (sesamum indicum) belongs to the plant family Pedaliacea commonly called beniseed in Nigeria. It is an important oilseed crop believed to have originated from tropical Africa, where there is the greatest genetic diversity. It was later taken at a very early date to India where a secondary centre of diversity was developed (Purseglove, 1969). Oplinger et al (1990) indicated it to be a highly prized oilseed crop in Babylon and Assyria about 4,000 years ago. 
In Nigeria, sesame is cultivated on over 80,000 ha across most of the Northern States for food and oil. Benue and Nasarawa States are the highest sesame producers in Nigeria with an annual average output of not less than 40,000MT (Raw Materials Research and Development Council, 2004). Although the name sesame is used in literature worldwide and also known as "simsim" in East Africa, "Till" in India and "Gingely" in Sri-Lanka, the Hausa, Ibo, and Yoruba, major tribes of Nigeria call it "Ridi", "Ekuku" and "Isasa," respectively. Other tribes in Nigeria also have names for it.

As a raw export commodity, sesame seed from Nigeria is enjoying a rising profile in the world market where overall global demand has risen to 3.3 million tons. Sesame is one of the major cash crops grown in Nasarawa State. It is a very popular crop among the rural farmers because of the good local and international markets for its seed and oil. There are already buyers from China and other parts of the Asian countries that patronize the product (Nasarawa State Government, 2008). The Southern agricultural zone is the major producer of sesame in Nasarawa state.

The impacts of global climate change on agricultural production are a serious source of worry to farmers in sub-saharan Africa. This is because their economies mainly depend on agriculture which is now affected by climate change catastrophes. Farmers' awareness and perception of these changes is therefore critical and of concern in Nigeria, particularly among sesame farmers in the study area where vulnerability is high because awareness and the ability to adapt are low.

The study's specific objectives were to determine farmers' perception of the effects of climate change; identify the perceived suitable adaptive measures employed by respondents; and identify sources of awareness of adaptive measures used to cope with the effects of climate change.

\section{Methodology}

Nasarawa State has thirteen local government areas (LGAs) and is divided into three agricultural zones namely: Central, Western and Southern agricultural zones respectively. The study was conducted in the Southern Agricultural Zone which comprises Lafia, Doma, Keana, Awe and Obi Local Government Areas (LGAs). The zone is characterized by long period of rainy season (March-October). The average annual rainfall is approximately $107.3 \mathrm{~mm}$ and annual temperature ranging from $22.7^{\circ} \mathrm{C}-36.8^{\circ} \mathrm{C}$ (Meteorological department, NSG, 2008). The major tribes are Alago,Eggon, Kanuri, Migili, and Gwandara. Others include Tiv, Hausa Fulani, Igbo, Yoruba and Ngas. Most of the people are farmers who engage in trading and artisan work as part time commercial activities. 
Sesame farmers in the zone constituted the population for the study. A multistage random sampling technique was used to select respondents. Two town communities were randomly selected from each of the five LGAs to give a total of ten town communities. They include Deddere and Olosoho (Obi), Amaku and Idadu (Doma), Kwandare and Shabu (Lafia), Ribi and Wuse (Awe) and and (Keana). Eighteen sesame farmers with long years of farm experience were purposively selected from each of the town community. The preference for farmers with long years of farm experience was made so as to gain the most useful information from them on their experiences of changes in climate as it affects their farming practices and production. This gave a sample size of 180 .

In order to characterize the respondents, issues on their socio economic characteristics such as age, marital status, farming experience, sex, educational level, membership of social organization, annual income and yield were ascertained. In identifying farmers perception of the effects of climate change, in depth literature reviews, expert opinions and observations were utilized in framing the questions used. Farmers were asked to tick options that apply to their perceptions of the effects of climate change and their sources of awareness. Simple descriptive statistics such as percentages, means and frequencies were used in analyzing data.

\section{Results}

\section{Socio-economic Characteristic of Sesame Farmers in the Study Area}

The socio-economic characteristics of the respondents are presented in Table 1. The result reveals that $40 \%$ and $37.8 \%$ of the respondents were within active ages of 20-30 and 31- 40 years, respectively. This result agrees with the findings of Yusuf (2005) that most farmers are within their active years and can make positive contribution to agricultural production. Some studies have found that age had no influence on farmers' decision to participate in forest and soil and water management activities (Thatcher et al., 1997; Anim, 1999; Zhang and Flick, 2001; Bekele and Drake, 2003). Others, however, found that age is significantly and negatively related to farmers' decision to adopt (Gould et al., 1989; Featherstone and Godwin, 1993). However, Okeye (1998) and Bayard et al. (2007) found that age is positively related to the adoption of conservation measures. In this study, we assumed that old age is associated with more experience and expect older farmers to have better understanding of the effects and adapt to climate changes. However we also expect young people to have a longer planning horizon to take up long adaptations measures such as irrigation and mixed crop livestock systems.

Analysis of gender in sesame production indicated that men comprised 53.3 percent whereas female comprised 47.7 percent. The result implies both males and females are involved in sesame production. These results disagree with the findings of Umar et al. (2011) who reported high male dominance in sesame 
production in the study area. The result also shows that 63.3 percent of the respondents were married. The high proportion of the respondents who are married is an indication that family labour could be available for sesame farmers.

The distribution of respondents according to educational level is in Table 1. It shows that majority (34.4\%) of the respondents had secondary education, 26.7 percent had non- formal education whereas 16.7 and 22.2 percent had primary and tertiary education respectively. This implies that most of the respondents were not well educated. Noor (1981) and Omolola (2005) documented the relevance of the literacy level of a farmer to farm productivity and production efficiency. They are of the view that education facilitates farmers' understanding and use of improved crop technologies. Furthermore, farmers' experience in sesame production had majority $(58.9 \%)$ of the farmers with less than 3 years farming experience, whereas 40 percent of the respondent had 3- 6 years farming experience. Table 2 shows that 46.7 percent of the respondents earned below \$50,000 per annum whereas 37.8 percent earned $\$ 50000-\$ 100000$ per annum. Those with higher annual income level of above $\$ 150,000$ were only 4.4 percent of the respondents. 
TABLE 1

Distribution of respondents according to their socioeconomic characteristics

\begin{tabular}{|c|c|c|c|}
\hline \multirow{2}{*}{$\begin{array}{l}\text { Variables } \\
\text { Age(yrs) }\end{array}$} & & Frequency & Percentage \\
\hline & $\begin{array}{l}20-30 \\
31-40 \\
41-50 \\
\text { Above } 50 \\
\text { Total }\end{array}$ & $\begin{array}{l}72 \\
68 \\
30 \\
10 \\
\mathbf{1 8 0}\end{array}$ & $\begin{array}{l}40 \\
37.8 \\
16.7 \\
5.6 \\
100\end{array}$ \\
\hline Sex & $\begin{array}{l}\text { Male } \\
\text { Female } \\
\text { Total }\end{array}$ & $\begin{array}{l}96 \\
84 \\
\mathbf{1 8 0}\end{array}$ & $\begin{array}{l}53.3 \\
46.7 \\
100\end{array}$ \\
\hline Marital status & $\begin{array}{l}\text { Married } \\
\text { Single } \\
\text { Total }\end{array}$ & $\begin{array}{l}114 \\
66 \\
\mathbf{1 8 0}\end{array}$ & $\begin{array}{l}63.3 \\
36.7 \\
100\end{array}$ \\
\hline Educational level & $\begin{array}{l}\text { Non formal } \\
\text { Primary } \\
\text { Secondary } \\
\text { Tertiary } \\
\text { Total }\end{array}$ & $\begin{array}{l}48 \\
30 \\
62 \\
40 \\
\mathbf{1 8 0}\end{array}$ & $\begin{array}{l}26.7 \\
16.7 \\
34.4 \\
22.2 \\
100\end{array}$ \\
\hline $\begin{array}{l}\text { Farming } \\
\text { experience(yrs) }\end{array}$ & $\begin{array}{l}<3 \\
3-6 \\
6-9 \\
\text { Total }\end{array}$ & $\begin{array}{l}106 \\
72 \\
2 \\
180\end{array}$ & $\begin{array}{l}58.9 \\
40 \\
1.1 \\
100\end{array}$ \\
\hline Yield (bags) & $\begin{array}{l}<3 \\
3-6 \\
7-10 \\
\text { Total }\end{array}$ & $\begin{array}{l}76 \\
80 \\
24 \\
\mathbf{1 8 0}\end{array}$ & $\begin{array}{l}42.2 \\
44.4 \\
13.3 \\
100\end{array}$ \\
\hline & $\begin{array}{l}<50000 \\
50001-100000 \\
100001-150000 \\
>150000 \\
\text { Total }\end{array}$ & $\begin{array}{l}84 \\
68 \\
20 \\
8 \\
180\end{array}$ & $\begin{array}{l}46.7 \\
37.8 \\
11.1 \\
4.4 \\
100\end{array}$ \\
\hline Social organization & $\begin{array}{l}\text { Non member } \\
\text { Member } \\
\text { Total }\end{array}$ & $\begin{array}{l}100 \\
80 \\
\mathbf{1 8 0}\end{array}$ & $\begin{array}{l}73.3 \\
27.7 \\
100\end{array}$ \\
\hline
\end{tabular}

Source: Field survey 


\section{Farmer perceptions of the effects of climate change in the study area}

Results in Table 2 show that majority of the respondents' perceived increase in rains $(73.3 \%)$, insects' infestation (68.9), torrential downpours (73.3\%), temperature changes $(70.0 \%)$ and soil erosion $(76.7 \%)$ as resulting from the effects of changes in climate in the area. This contradicts the study on Tologbonse et al., (2010) on farmers perception of climate change where they found that farmers perceived increase in temperature as being the highest effect of climate change however, the study agrees that climate change increases flooding which results in soil erosion, thus degrading soil fertility and quality which invariably reduces agricultural productivity. On the other hand, $26.7 \%$ and $48.9 \%$ of the respondents perceived draught and dry spells and increase in evaporation of soil moisture respectively to be caused by climate change in the area.

\section{TABLE 2}

Distribution of respondents according to their perception of the effects of climate change

\begin{tabular}{lll}
\hline Effects of climate change & ${ }^{*}$ Frequency & Percentage \\
\hline Draught and dry spells & 48 & 26.7 \\
Increase rains & 132 & 73.3 \\
Increase evaporation of soil moisture & 88 & 48.9 \\
Insects infestation & 124 & 68.9 \\
Torrential downpours & 132 & 73.3 \\
Temperature changes & 126 & 70 \\
Soil erosion & 138 & 76.7 \\
\hline
\end{tabular}

Source: Field survey

*Multiple responses are considered

\section{Perceived adaptation strategies of sesame farmers}

The results (Table 3 ) show that use of insect's powder, use of chemicals, early harvesting and early planting had over $50 \%$ of the respondents agreeing that they perceived this practices to be the suitable practices they adopted as adaptive measures to cope with the effects of climate change. Whereas, mixed cropping, improved seed variety and increase soil water conservation had $41 \%, 47.8 \%$ and $33.3 \%$ respectively of the respondents who opted for them as suitable adaptive measures to cope with the effects of climate change. 
TABLE 3

\section{Distribution of respondents according to the adaptive measures adopted}

\begin{tabular}{lll}
\hline Adaptive measures & ${ }^{\star}$ Frequency & Percentage \\
\hline Mixed cropping & 74 & 41.1 \\
Improved seed variety & 86 & 47.8 \\
Early planting & 98 & 54.4 \\
Early harvesting & 102 & 56.7 \\
Use of chemicals & 104 & 57.8 \\
Increase soil water conservation & 60 & 33.3 \\
Use of insects powder & 114 & 63.3 \\
\hline
\end{tabular}

Source: Field survey

${ }^{*}$ Multiple responses are considered

\section{Sources of awareness}

Results in Table 3 show extension agents (76.7\%), educated farmers (83.3\%) and radio and television (61.1\%) had majority of the respondents agreeing that they are their sources of awareness of effects of climate change and the adaptive measures to cope with such changes. Whereas, $52.2 \%, 28.9 \%$ and $18.9 \%$ of the respondents identified friends (Non farmers), nongovernmental organizations and newspapers as their sources of awareness of the effects and adaptive measures to cope with the effects of climate change respectively.

Awareness of the effects of climate changes through appropriate and reliable sources is an important determinant of adoption of suitable adaptive measures to cope with such changes. Maddison (2007) found that farmers' awareness of changes in climate attributes is important for adaptations decision making. Several studies have found that farmer's awareness and perceptions of soil erosion problems positively and significantly affected their decisions to adopt suitable adaptation measures (Gould et al., 1989; Traore et al., 1998; Anim, 1999; Aray \& Adjaye, 2001). It is expected that farmers who notice and are aware of changes in climate would take up adaptation measures that help them reduce losses or take advantage of the opportunities associated with these changes. 
TABLE 4

Distribution of respondents according to their sources of awareness of the effects of climate change and their adaptive measures

\begin{tabular}{lll}
\hline Sources of Awareness & ${ }^{*}$ Frequency & Percentage \\
\hline Extension agents & 138 & 76.7 \\
Educated farmers & 150 & 83.3 \\
Newspapers & 34 & 18.9 \\
Friends (Non farmers) & 94 & 52.2 \\
Non-Governmental organizations & 52 & 28.9 \\
Radio and Television & 110 & 61.1 \\
\hline
\end{tabular}

Source: Field survey

${ }^{*}$ Multiple responses are considered

\section{Conclusion}

The results of this study revealed that majority of the respondents were still within their active ages of between 20-30 and 31-40 years respectively. Sesame production in southern agricultural zone of Nasarawa State is both male and female dominated enterprise. It was revealed that majority $(34.4 \%)$ of the respondents had secondary education, 26.7 percent had non-formal education whereas 16.7 and 22.2 percent had primary and tertiary education respectively. The results show that Use of insect's powder, Use of chemicals, Early harvesting and Early planting had over $50 \%$ of the respondents agreeing that they perceived this practices to be the suitable practices they adopted as adaptive measures to cope with the effects of climate changes. It was also revealed that extension agents $(76.7 \%)$, educated farmers (83.3\%) and radio and television (61.1\%) had majority of the respondents agreeing that they are their sources of awareness of effects of climate changes and the adaptive measures to cope with such changes. Others identified friends (Non farmers), nongovernmental organizations and newspapers as their sources of awareness of the effects and adaptive measures to cope with the effects of climate change.

\section{Recommendations}

In view of the findings in this study, the paper recommends that agricultural extension service should play a crucial role of informing its clientele (farmers) on how best to adapt to climate change impacts. This will require some further training on the part of the extension personnel in order to build their own capacity to effectively strengthen farmers" capacities. Researchers and extensionists must as a matter of urgency work closely with sesame farmers to create awareness on the effects of climate changes as it affects their farming activities. They must also strengthen the confidence of farmers by expressing faith in such adaptive measures for a sustainable agricultural development 
Effective education and training to build and strengthen the capacity of farmers is needed since the study revealed that farmers' have low educational qualifications. This will enable farmers and people in the area to respond proactively to the impacts of climate change and climate variability and understand the scientific principle at work in their environment and also stimulate them to know better adaptive strategies to climate change. Therefore, government and nongovernmental organizations should design effective adult literacy programmes and policies in the area which will encourage farmers to improve on their educational levels.

\section{References}

Anim, F.D.K (1999). The adoption of soil conservation measures in the Northern Province of South Africa. Journal of Agricultural Economics 50, 336-45.

Araya, B. and Adjaye, J. A. (2001). Adoption of farm level soil Conservation practices in Eritrea. Indian Journal of Agricultural Economics 56, 239-52.

Bayard, B., Jolly, C. M. and Shannon, D. A. (2007). The economics of adoption and management of alley cropping in Haiti. Journal of Environmental Management. 84, 62-70.

Bekele, W. and Drake, L. (2003). Soil and water conservation decision behavior of subsistence farmers in the Eastern Highlands of Ethiopia: A case study of the Hunde-Lafto Area. Ecological Economics 46, 437-51.

Featherstone, A. M. and Godwin, B. K. (1993). Factors influencing a farmer's decision to invest in long-term conservation improvements. Land Economics 69, 67- 81.

Gould, B. W., Saupe, W. E. and Klemme, R. M. (1989). Conservation tillage: The role of farm and operator characteristics and the perception of soil erosion. Land Economics 65, 167-82.

Maddison, D. (2006). The perception of and adaptation to climate in Africa. CEEPA Discussion paper No.10. Centre for Environmental Economics and Policy in Africa, University of Pretoria.

Nasarawa State Government. (2006). Ministry of Information, Lafia Annual Report.

Noor, A. (1981). Educational and Basic Human Needs. World Bank Working Paper No. 450.

Okoye, C. U. (1998). Comparative analysis of factors in the adoption of traditional and recommended soil erosion control practices in Nigeria. Soil and Tillage Research 45, 251-63. 
Omolola, A. S. (2005). Agribusiness credit in Nigeria: Dimensions of Institutional and Policy Deficiency. A paper presented at the third National Conference of ARMTH in Ilorin. In: G.C Onubougu and B.C Nnadozie (Eds): Agricultural Rebirth in Nigeria. Proceedings of the $39^{\text {th }}$ Annual Conference of the Agricultural Society of Nigeria. University of Benin, Nigeria, Pp44-49.

Oplinger, E.S., Putnam, D.H., Kaminski, A.R., Hanson, C.V., Oelke. E.A., Schulte, E.E.and Doll, J.D. (2007). Alternative Field Crops Mannual: Sesame. Retrieved from http://www.hort.purdue.edu/newcrop/afcm/sesame.html.

Purseglove, J.W. (1996). Tropical Crops. Longman, London, 435pp.

Thacher, T., Lee D. R. and Schelhas, J. W. (1997). Farmer participation in reforestation incentives programmes in Costa Rica. Agro-forestry Systems 35 (3), 269-89.

Tologbonse, E.B., Auta S.J., Bidoli, T.D., Jaliya, M.M., Onu, R.O. And Isa, F.O. (2010). Farmers perception of the effects of climate change and coping strategies in three agro-ecologicaal zones of Nigeria. Journal of Agricultural Extension. 14 (1), $144-156$

Traore, N, Landry, R. and Amara, N. (1998). On-farm adoption of conservation practices: The role of farm and farmer characteristics, perceptions and health hazards. Land Economics 74, 114-27.

Umar, H. S., Okoye, C. U. and Agwale A. O. (2011) Productivity analysis of sesame production under organic and inorganic fertilizers applications in Doma Local Government Area, Nasarawa State, Nigeria. Tropical and Subtropical Agroecosystems 14 (1), 405-411

Yusuf, O. (2005). Economics analysis of 'egusi' melon production in Okehi Local Government Area of Kogi State, unpublished M.Sc. Thesis, Department of Agricultural Economics and Rural Sociology, Ahmadu Bello University, Zaria, Pp. 40-41.

Zhang, D. and Flick, W. (2001). Sticks, carrots and reforestation investments. Land Economics 77 (3), 443-56. 